\title{
The Analysis of Three Dimension Aspects of the Main Character in the Novel The Short Second Life of Bree Tanner
}

\author{
Ida Ayu Febi Dwi Sangastu ${ }^{1^{*}}$, I Gusti Agung Istri Aryani ${ }^{2}$ \\ English Department - Faculty of Arts - Udayana University \\ ${ }^{1}$ [idaayufebi@gmail.com],_[ig_aryani@yahoo.com] \\ *Corresponding Author
}

\begin{abstract}
Literature is one of the written works that express aspect of human life. This study is using a novel entitled The Short Second Life of Bree Tanner. It is analyzing the main character in terms of physiological, psychological, and sociological dimension aspects. Dramatic and character on the other character method were used in analyzing the study based on character dialogue, action, opinion, and feeling. These were explained descriptively in order to have a clear understanding of the aspects implied in the story. The result of findings were three dimension aspects, as of; physiological, that influenced the main character are the age and physical appearance. The psychological, about the situation that she was ran away from her father when she still human. The sociological background and human relationship are influenced in sociological aspect. It can be concluded that the whole three dimension aspects of the main character showed in physiological, Bree was fifteen years old girl almost sixteen years old when she became a vampire, but she did not remember how old she was when she was a human. Her body will sparkling like a crystal when exposed to sunlight and also have a bright and red eyes. In psychological, she is an introvert vampire with few friends and does not really like to make trouble andspare time with other vampire. In sociological, before became a vampire, Bree was a girl who lived with her father. But, after her mother died, her relationship with her father not good, because her father was rude person.
\end{abstract}

Keywords: Literature, main character, three dimension aspects.

\begin{abstract}
Abstrak
Sastra adalah salah satu karya tulis yang mengekspresikan aspek kehidupan manusia. Penelitian ini menggunakan novel berjudul The Short Second Life dari Bree Tanner. Penelitian ini menganalisis karakter utama dalam hal aspek dimensi fisiologis, psikologis, dan sosiologis. Karakter drama dan karakter pada metode karakter lainnya digunakan dalam menganalisis penelitian berdasarkan dialog karakter, tindakan, pendapat, dan perasaan. Ini dijelaskan secara deskriptif agar bisa memahami secara jelas aspek-aspek yang tersirat dalam cerita. Hasil temuan adalah aspek tiga dimensi, antara lain; Fisiologis, yang mempengaruhi karakter utamanya adalah usia dan penampilan fisik. Secara psikologis tentang situasi bahwa dia lari dari ayahnya saat dia masih manusia. Latar belakang sosiologis dan hubungan manusia dipengaruhi aspek sosiologis. Dapat disimpulkan bahwa keseluruhan aspek tiga dimensi dari karakter utama menunjukkan secara fisiologis, Bree adalah gadis berusia lima belas tahun yang hampir enam belas tahun saat ia menjadi vampir, namun ia tidak ingat berapa umur dirinya ketika ia masih seorang manusia. Tubuhnya akan berkilau seperti kristal saat terkena sinar matahari dan juga memiliki mata yang cerah dan merah. Secara psikologis, dia adalah vampir introvert dengan sedikit teman dan tidak terlalu suka membuat masalah dan waktu luang dengan vampir lainnya. Secara sosiologis, sebelum menjadi vampir, Bree adalah seorang gadis yang tinggal bersama ayahnya. Tapi, setelah ibunya meninggal, hubungannya dengan ayahnya tidak baik, karena ayahnya orangnya kasar.
\end{abstract}




\section{Kata kunci: sastra, karakter utama, tiga dimensi aspek.}

\section{Background of the Study}

Semi (1988: 8), conveys that literature is a form of universal culture, a product of creative art, of which the object is human that is formed by language which has an aesthetic value. Literature does not only describe the problem of life, but also about society. Literature is creativity, an artwork that must always have a structure and an aesthetic value art, a total coherence and effect. Literary works can be divided into three main genres such as poetry, drama, and novel (Warren, 1955: 219). One of literary works chosen in this study is novel. Novel is a long piece of prose and contains a series of stories of one's life with others by highlighting the character and nature of each actor. Novel is medium to pour the thoughts, feeling, and ideas of the author in responding to life around him (Nurgiyantoro, 2010: 9).

The intrinsic element provides the elements which build up the structure of literary works. In the novel The Short Second Life of Bree Tanner, there are four characters that have important role in the story, as of: Bree Tanner as the main character, and the other three characters are Diego, Fred, and Riley as the secondary or peripheral characters. Character is person in literary work. The existence of character is important to the story, because the purpose of reading a story is to find out what happens or to see how the plot works, an equally compelling reason is to follow the fortunes of the character.

The main character is most important in the story to tell about his or her experience. Almost all novels start the story with the main character described in detail first and started to get into the story. The main character has a central point in the story, because of a problem in the story that made sure that there is always a connection with the main character.

Three dimension aspects presented in the main character, they are: physiological, psychological, and sociological dimension aspects. Physiological dimension of the character is the physical appearance which includes some physical aspects, such as skin color, eye color, sex, age, heredity, size, etc. Psychological dimension is interested in everything related to the character's activities and experience. Sociological dimension is the social relationship of the characters, consisting of family, religion, occupation, belief, economic, status, social activity, etc.

The novel The Short Second Life of Bree Tanner is spin-off of the third book series entitled Eclipse. The story is related to novel Eclipse which is told from another point of view, namely from the perspective of one vampire named Bree Tanner who is the main character in this novel.

\section{Problem of the study}

In analyzing the three dimension aspects of the main character of the novel The Short Second Life of Bree Tanner, the problems raise in this study are formulated into the following questions:

a. What are physiological, psychological, and sociological dimensions of the main character?

b. What are the methods of characterization used in terms of physiological, psychological, and sociological dimensions?

\section{Aims of the Study}

This study has some aims as follows:

a. To describe the physiological, psychological, and sociological 
dimensions of the main character.

b. To find out the methods of characterization used in terms of physiological, psychological, and sociological dimensions.

\section{Research Method}

The research method in this study consists of data source, method and technique of collecting data, method and technique of analysing the data, and method and technique of presenting data.

\subsection{Data source}

The data in this study were taken from the novel entitled The Short Second Life of Bree Tanner, written by Stephenie Meyer. This novel was published in June 2010 in the United States. It is interested to analyze the three dimensions of the main character of this novel, because the novel illustrates clearly how the Bree Tanner life from the point of view of herself.

\subsection{Method and Technique of Collecting Data}

The method and technique of collecting data used in this study is the documentary method. It means that the data were collected by reading the novel. The processes of collecting data are; first, by reading the novel repeatedly and intensively to understand the novel. Then, identifying, selecting, and taking note of which part of the novel provides the information about the three dimensions of the main character.

\subsection{Method and Technique of Analysing Data}

The collected data was qualitativelyanalysed, based on the theory by Egri to find three dimensions.
The methods of characterization in the story were further based on the theory proposed by Kenny.

\section{Analysis}

\subsection{Three Dimensions in the Novel} The Short Second Life Of Bree Tanner a. Physiological Dimension

Bree Tanner is a girl who turned into a vampire after bitten by Riley who is a vampire and wants to create new vampires. Besides, she wanted to fight with another vampire called The Cullens. Bree became a vampire when she was fifteen years old, but she did not remember how old she was when she was a human being.

'How old are you?' he asked abruptly.

'Three months. I told you that.'

'That's not what I meant. Um, how old were you? I guess that's the right way to ask.'

I leaned away, uncomfortable, when I realized he was talking about human stuff. Nobody talked about that. Nobody wanted to think about it. But I didn't want to end the conversations, either. Just having a conversation at all was something new and different. I hesitated, and he waited with a curious expression.

'I was, um, I guess fifteen. Almost sixteen. I can't remember the day...was I past my birthday?' I tried to think about it, but those last hungry weeks were a big blur, and it hurt my head in a weird way to try to clear them up. (Meyer, p. 28-29: 2010).

\section{b. Psychological Dimension}

It is part of her habits to hide behind Fred. Actually, Bree is a vampire who does not like to make trouble and always obey rules. Often hide behind Fred's body so other new vampires did not realize that 
she was in that place. These can be seen as follows:

If I were being honest with myself, I'd pretty much turned into a huge vampire nerd.I followed the rules, I didn't cause trouble, I hung out with the most unpopular kid in the group, and I always got home early. (Meyer, p. 24: 2010)

\section{c. Sociological Dimension}

After becoming a vampire, Bree with the other new vampires live in Seattle, and they move often from place to place. The house they occupied is a house which belongs to owners who are died. Its location was far away from human places. It is located on a mountain, island, or hidden in large farm. They chose these kinds of places so others cannot realize on their existence.

Every house we'd borrowed, whether it was up a mountain or on an island or hidden on a big farm, had a few things in common. The dead owners, the remote locale, and one other thing. They all were sort of focused on Seattle. Oriented around the big city like orbiting moons. Seattle was always the hub, always the target.

The house was a big, log cabin-style affair, tucked into a hollow in the pines with no sign of any neighbors for miles around. All the windows were black, as if the place were empty, but the whole frame was trembling from the heavy bass in the basement. (Meyer, p. 54 and 56: 2010).

\subsection{Method of Characterization in Presenting Bree Tanner as the Main Character}

\section{A. Dramatic Method}

As a vampire Bree Tanner's body will glow like crystal when exposed to sunlight.
'Unreal,' Diego whispered. He put the rest of his hand into the beam, and the cave somehow got even brighter. $\mathrm{He}$ rolled his hand over to look at the back, then turned it palm up again. The reflections danced like he was spinning a prism.

There was no smell of burning, and he clearly wasn't in pain. I looked closely at his hand, and it seemed like there were a zillion tiny mirrors in the surface, too small to distinguish separately, all shining back the light with double the intensity of a regular mirror.

'Come here, Bree - you have to try this.'

'I couldn't think of a reason to refuse, and I was curious, but I was also still reluctant as I slid to his side.

'No burn?'

'None. Light doesn't burn us, it just... reflects off of us. I guess that's kind of an understatement.'

Slow as a human, I reluctantly stretched my fingers into the light. Immediately, reflection blazed away

\section{Conclusion}

Bree Tanner as the main character has important part in this story and central position in the whole story. Diego, Fred, and Riley are considered the peripheral or secondary characters in the story, because they give great influence to the main character. The function of the secondary characters is to illuminate the main characters.

Even though, they do not appear continually in every event, but indirectly they influence the main character.

Physically, Bree Tanner was a girl fifteen years old girl or almost sixteen years old when she became a vampire, but she did not remember how old she was when she was a human. Her body will sparkle like a crystal when exposed to sunlight and also hasbright and red eyes. Psychologically, Bree is an introvert 
vampire with few friends and does not really like to make trouble and spare time with other vampires. Sociologically, before becoming a vampire, Bree was a girl who lived with her parents. But, after her mother died, Bree's relationship with her father was not good, because her father was a rude person.

Based on characterization, it can be concluded that the methods used by the author of this novel are dramatic and characters on the other characters method used in the story. Meanwhile, the three dimensions of Bree Tanner (Physiological, Psychological, and Sociological) are mostly presented through the dramatic method because Bree Tanner is the narrator of the story.

\section{Bibliography}

Kenny, W. (1966).How to Analyze Fiction.New York: Monarch Press. Kong. Oxford University Hong Kong Press.

Meyer, S. (2010). The Short Second Life of Bree Tanner.Little, Brown and Company. New York.

Nugriyantoro, B. (2010). Theory PengkajianFiksi.GadjahMada

University 'Passion's Promise (script). Denpasar: Udayana University.

Semi, A. M. (1988).AnatomiSastra. Padang: Angkasa Raya Padang.

Warren, A. and W.R.(1955). Theory of Literature.London: Jonathan Cape. 